Vol 2 (2) 2020, 40-44

\title{
Validasi Metode Analisa Amonia pada Air Tanah Menggunakan Metode Spectrofotometri
}

\author{
Muryanto ${ }^{1}$ \\ ${ }^{1}$ Fakultas Geografi, Universitas Gadjah Mada, Yogyakarta, email:65.Muryanto@gmail.com
}

Submisi : 15 Agustus 2019; Penerimaan: 26 Februari 2020

\begin{abstract}
ABSTRAK
Amonia dilepas kedalam air oleh adanya penguraian organik dan juga sebagai buangan metabolik organisme perairan. Amonia (NH4) merupakan senyawa nitrogen, Pada bentuk cairan, amonia terdapat dalam 2 bentuk yaitu amonia bebas atau tidak terionisasi (NH3) dan dalam bentuk ion amonia $\left(\mathrm{NH}^{+}\right)$.

Penelitian ini menggunakan spertrofotometer. Tujuan dari penelitian ini adalah mendapatkan metode yang valid untuk penetapan kadar ammonia. Validitas metode ditunjukkan melalui parameter selektivitas, linearitas, LLOD, LLOQ, presisi, dan akurasi (\% recovery). Panjang gelombang yang digunakan yaitu $425 \mathrm{~nm}$. Lineritas kurva baku unsur amonia $r=0,996$ dan $K V=$ 1.99. Nilai $L O D$ dan $L O Q$ yang dihasilkan parameter Amonia adalah 0,0032 ppm dan 0,0107 ppm. \% Recovery parameter Amonia sebesar 98.929\%, Presisi yang ditunjukkan dengan nilai KV memenuhi persyaratan validasi. Dengan hasil tersebut, maka dapat disimpulkan bahwa metode analisis parameter ammonia pada air tanah di Kecamatan Gondokusuman, Yogyakarta memenuhi persyaratan validasi.
\end{abstract}

Kata Kunci : Amonia, Validasi, Spectrophotometer.

\section{PENDAHULUAN}

Validasi merupakan konfirmasi melalui pengujian dan pengadaan bukti yang obyektif bahwa persyaratan tertentu untuk tujuan khusus dipenuhi. Menurut SNI 19-170252017, Salah satu klausulnya menyebutkan bahwa laboratorium harus memvalidasi metode tidak baku, metode yang dikembangkan, dan metode baku yang digunakan di luar lingkup yang dimaksudkan (Anonim, 2005).

Tujuan dari penelitian ini adalah mendapatkan metode yang valid untuk penetapan kadar ammonia. Hasil uji yang absah apabila hasil validasinya diperoleh akurasi (ketepatan) dan presisi (kecermatan) yang baik. Akurasi dinyatakan dengan nilai recovery yang dihitung dari kadar terukur dibagi dengan kadar diketahui dikalikan 100 $\%$, jika nilainya berada pada rentang $90-110 \%$ maka metode ini dikatakan baik. Presisi metode analisis dihitung berdasarkan Coefficient of Variation (CV) yang dihitung dari simpangan baku dibagi nilai rata- rata dikalikan 100\%, jika nilainya kurang dari $2 \%$ maka metode ini presisinya baik (Mulja, 2003)

Metode uji memegang peranan yang sangat penting dalam memperoleh hasil uji dengan akurasi dan presisi tinggi. Salah satu alat uji yang mendukung laboratorium penguji. di Laboratorium Hidrologi dan Klimatologi lingkungan adalah spektrofotometer. Sehingga tujuan penelilian ini adalah 
melakukan validasi metode nitrat dalam air tanah.

Amonia dilepas kedalam air oleh adanya penguraian organik dan juga sebagai buangan metabolik organisme perairan. Amonia (NH4) merupakan senyawa nitrogen. Pada bentuk cairan, amonia terdapat dalam 2 bentuk yaitu amonia bebas atau tidak terionisasi (NH3) dan dalam bentuk ion amonia $\left(\mathrm{NH}^{+}\right)$. Standar kualitas air menggunakan bentuk total ammonia. Amoniak merupakan senyawa nitrogen yang menjadi $\mathrm{NH}_{4}$ pada $\mathrm{pH}$ rendah. Amoniak dalam air buangan industri berasal dari oksidasi bahan - bahan organik oleh bakteri diubah menjadi $\mathrm{CO}_{2}, \mathrm{H}_{2} \mathrm{O}, \mathrm{NH}_{3}$. Untuk mengetahui apakah sumur penduduk sudah terjadi pencemaran diperlukan analisa air tanah di laboratorium. Ada beberapa metode dalam analisa air, salah satunya adalah metode spektrofotometri.

\section{BAHAN DAN METODE}

\section{Obyek Penelitian}

Obyek penelitian adalah air tanah di kecamatan Gondokusuman Yogyakarta sebanyak 5 sample yang diambil 3 sampel dari daerah dekat sungai dan 2 dari daerah penduduk yang jauh dari sungai.

Pengambilan sampel masing-masing 1 liter air untuk dimasukkan dalam botol yang sebelumnya telah dibersihkan dan dibilas dengan air sampel itu sendiri. Sampel sebaiknya harus mengisi botol pengambilan hingga penuh dan botol harus ditutup dengan baik untuk menghindari kontak dengan udara.

\section{Pengumpulan Data}

Metode pengumpulan data dalam penelitian ini adalah: metode observasi untuk mengamati secara langsung keadaan di lapangan sejak awal yaitu pada saat survai hingga pelaksanaan penelitian. Peneliti mengamati daerah yang dekat dengan sungai dan, daerah yang jauh dari sungai. Data yang digunakan dalam penelitian adalah dari analisa di laboratorium .

\section{Bahan Penelitian}

Bahan - bahan yang digunakan dalam penelitian ini adalah :

- sampel air tanah.

- Larutan standard $\mathrm{NH}_{4} \mathrm{Cl} 1,00$ $\mathrm{ml}=0,002 \mathrm{mg} \mathrm{N}$

- Reagen Nessler

\section{Alat Penelitian}

Alat - alat yang digunakan dalam penelitian ini antara lain adalah :

- Botol sampel ukuran 1 liter.

- Water sampler 1 buah untuk mengambil sampel air.

- E.C.meter 1 buah untuk mengukur daya hantar listrik dilapangan.

- Spectrofotometer

- tabung reaksi

- pipet

- glass beker

- labu takar

- alat tulis menulis

- Seperangkat computer

- GPS ( Global Positioning System)

- Peta Rupa Bumi 1:25.000.

\section{Langkah-langkah penelitian}

1. Tahap Pengambilan Sampel

Dalam tahap ini kegiatan yang dilakukan meliputi : Pengambilan sampel air tanah di daerah yang dekat dengan sungai dan daerah yang jauh dengan sungai. Air tanah yang diambil dilakukan dengan water sampler, setelah itu dimasukkan ke dalam botol sampel. Sebelum pengambilan sampel air tanah dan botol sampel yang digunakan, dicuci dahulu dengan air yang akan di ambil, Pemeriksaan sampel air tanah dilakukan di Laboratorium Hidrologi dan Klimatologi Lingkungan Fakultas Geografi UGM.

2. Parameter yang diteliti 
Parameter yang diteliti adalah ammonia menggunakan spektrofotometer dan menggunakan Baku Mutu Peraturan Gubernur Daerah Istimewa Yogyakarta Nomor 20 tahun 2008. Tentang Baku Mutu Air di Provinsi Daerah Istimewa Yogyakarta.

\section{Analisis Laboratorium}

Analisis laboratorium dilakukan di Laboratorium Hidrologi dan Klimatologi lingkungan Fakultas Geografi UGM. Langkah selanjutnya air sampel yang telah diambil untuk dilakukan pengujian dilaboratorium. Adapun parameter yang digunakan dalam uji laboratorium adalah Amonia. Pengukuran Amonia (NH4) dilakukan menggunakan spektrofotometer Genesys 20, bekerja dengan metode pengukuran kuantitatif yang didasarkan pada pengukuran absorbsi (penyerapan) radiasi gelombang elektromagnetikya. Adapun Analisa di laboratorium yang dijalankan meliputi uji:

a. Linearitas.

Larutan standart dibuat pada konsentrasi 0.020, 0.040, 0.060, 0.080, 0.100 $\mathrm{mg} / \mathrm{L}$. Luas area yang dihasilkan dicatat dan dibuat persamaan linier hubungan antara kadar dan luas area yang dihasilkan. Nilai $r$ dari persamaan tersebut menggambarkan linieritas. Persamaan dinyatakan linier jika nilai $r$ yang diperoleh lebih besar dari $r$ tabel. b. Ketelitian.
Kadar sampel ditetapkan berdasarkan kurva baku yang sudah diperoleh. Selanjutnya dihitung kadar rata-rata, SD dan CV. Metode dinyatakan teliti jika CV $\leq 2 \%$ (Snyder dkk., 1997; Miller \& Crowther, 2000). c. Batas Deteksi LOD dan LOQ

Batas deteksi dihitung berdasarkan persamaan kurva baku yang sudah diperoleh (Anonim, 2006).

d. Ketepatan (accuracy)

Pengujian dilakukan dengan menambahkan sejumlah analit murni ke dalam campuran pembawa. Kemudian campuran dianalisis dan hasilnya dibandingkan terhadap kadar analit yang ditambahkan (kadar sebenarnya). Kriteria tepat diberikan jika hasil analisis memberikan perolehan kembali antara 98-102\% (AOAC, 2002).

\section{HASIL DAN PEMBAHASAN}

Dalam penelitian ini telah diambil 5 sampel air tanah. Setelah itu, sampel air tanah yang berasal dari sumur penduduk di daerah penelitian sesegera mungkin dianalisis dilaboratorium sehingga hasil yang didapatkan kekuratan data terjaga. Analisis yang dilakukan di laboratorium menggunakan metode spektrofotometri dengan panjang gelombang $425 \mathrm{~nm}$. Hasil pembacaan dari grafik standart disajikan dalam Gambar 1.

\section{Kurva Standart Amonia}

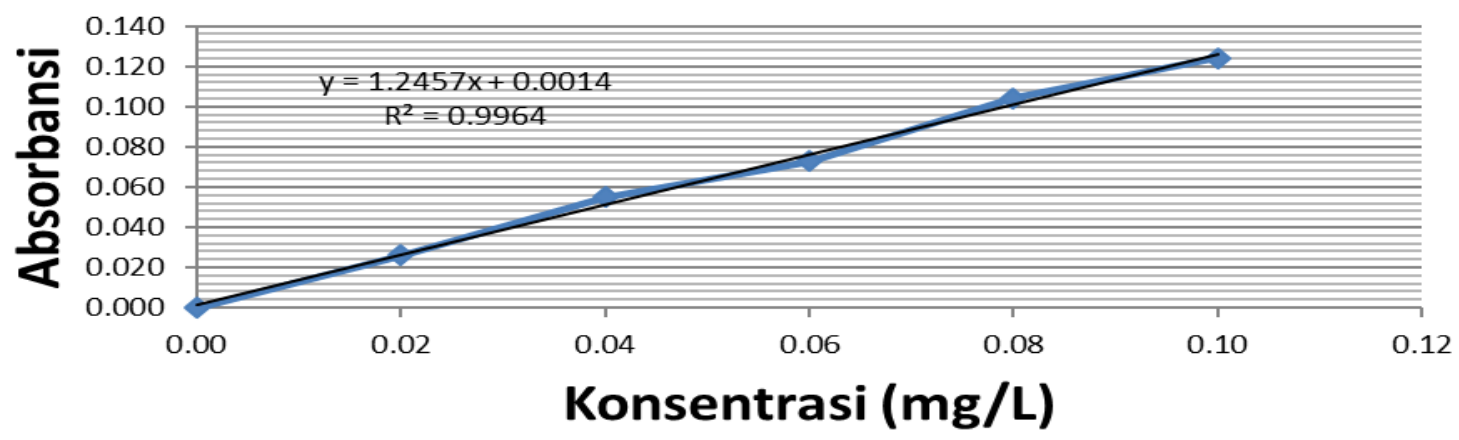

Gambar 1. Kurva Standart Amonia 


\section{Uji Linearitas}

Metode analisis biasanya didasarkan pada literature yang sudah ada menggunakan instrument yang sama atau hamper sama (Rohman, 2007) oleh karena itu perlu dilakukan validasi metode diawali dengan pembuatan krva kalibrasi dan linearitas. Dalam penelitian ini kurva kalibrasi diperoleh dengan cara membuat konsentrasi untuk nitrat 2 ppm, 4 ppm, 6 ppm, 8 ppm dan 10 ppm.

Persamaan kurva kalibrasi merupakan hubungan antara sumbu $x$ dan sumbu $y$ dimana sumbu $x$ dinyatakan dengan konsentrasi yang diperoleh, sedangkan sumbu y merupakan absorbansi atau serapan yang diperoleh dari hasil pengukuran, sehingga persamaan regresi linear dari kurva kalibrasi yang diperoleh untuk Amonia adalah $y=1.245 x+0.001$ dengan koefisien korelasi $r$ $=0.996$.

\section{Uji Ketelitian}

Salah satu persyaratan yang mendasar dalam suatu analisis adalah ketepatan dan ketelitian. Dalam penelitian ini untuk mendukung validasi metode digunakan parameter penelitian. Selanjutnya untuk mengukur parameter presisi yang menunjukkan derajat kesesuaian antara hasil uji yang diukur melalui penyebaran hasil dari rata - rata secara terulang. Presisi diukur sebagai simpangan baku atau simpangan baku relatif (koefisien variasi) berdasarkan penelitian yang dilakukan terhadap replikasi sampel yang diambil dari campuran yang homogen (Harmita, 2004). Dengan kata lain metode dapat menghasilkan nilai rata-rata yang sangat dekat dengan nilai sebenarnya dimana simpangan baku (SD) dan koefisien variasi (KV) sebagai parameter ukur. Adapun hasil perhitungan simpangan baku (SD) dari data yang diperoleh dan 7 kali replikasi pada konsentrasi 0.04 ppm sebesar 0.0008 dengan nilai koefisien variasi (KV) sebesar $1.99 \%$, menurut Harmita, 2004, nilai koefisien variasi
$<2 \%$ menunjukkan bahwa metode tersebut memberikan presisi yang baik.

\section{Pengujian Batas Uji dan Batas Deteksi}

Setelah mendapatkan kurva kalibrasi yang memenuhi persyaratan analisis,selanjutnya data yang diperoleh dari konsentrasi tiap analit yang memberikan absorbansi berbeda selanjutnya diolah untuk menentukan batas deteksi (LOD) dan batas kuantitas (LOQ). Batas deteksi merupakan konsentrasi analit terendah dalam sampel yang masih dapat dideteksi (Harmita, 2004) dan batas deteksi untuk Nitrat yang diperoleh adalah 0.0032 sedangkan batas kuantitas yang diperoleh 0.0107 .

\section{Penentuan Ketepatan}

Jumlah analit yang ditambahkan ke dalam sampel atau selisih antara rata-rata dan nilai sebenarnya yang dapat diterima menunjukkan ketepatan. Dalam hal ini ketepatan dihitung sebagai persen recovery (perolehan kembali). Hasil perhitungan menunjukkan bahwa perolehan kembali antara $98.929 \%$ sehingga metode analisa yang digunakan diharapkan akan memberikan data mendekati dengan yang sebenarnya (AOAC, 2002 dan Ermer dan Miller, 2005).

Penentuan Kadar Amonia dalam air tanah. Hasil analisis sampel yang dilakukan terhadap 5 sampel air tanah didapatkan disajikan dalam Tabel 1.

Tabel 1. Hasil analisis laboratorium terhadap sampel air tanah di daerah penelitian

\begin{tabular}{|cccc|}
\hline No & Serapan & ppm & $\begin{array}{c}\text { Baku } \\
\text { Mutu } \\
\text { (ppm) }\end{array}$ \\
\hline Sumur I & 0.009 & 0.0080 & $0.5^{\star}$ \\
Sumur II & 0.011 & 0.0096 & \\
Sumur III & 0.030 & 0.0249 & \\
Sumur IV & 0.035 & 0.0289 & \\
Sumur V & 0.047 & 0.0385 & \\
\hline
\end{tabular}

* baku mutu air Peraturan Gubernur Daerah Istimewa Yogyakarta nomor 20 tahun 2008 tentang Baku Mutu Air di Provinsi Daerah Istimewa Yogyakarta 
Sampel air yang diambil dari DAS Code Yogyakarta di analisa di Laboratorium Hidrologi dan Klimatologi Lingkungan untuk dianalisa. Dari 5 sampel yang dianalisa mempunyai kandungan Amonia terendah $0.0080 \mathrm{mg} / \mathrm{L}$ terdapat pada sampel sumur I dan tertinggi $0.0385 \mathrm{mg} / \mathrm{L}$ terdapat pada sampel sumur V. Berdasarkan hasil analisa maka semua sampel air sumur masih memenuhi baku mutu.

\section{KESIMPULAN}

Berdasarkan penelitian validasi metode spektrofotometri pada pengujian kadar Amonia, menjukkan metode ini memiliki akurasi yang tinggi, sehingga hasil uji bisa dipertanggung jawabkan.

\section{DAFTAR PUSTAKA}

Alaerts G, Sri Simestri Santika, 1987. Metoda Penelitian air. Surabaya. Penerbit Usaha Nasional

Anonim., Persyaratan Umum Kompetensi Laboratorium Pengujian dan Laboratorium Kalibrasi, SNI 1917025-2005, Badan Standardisasi Nasional, Jakarta (2005)

Anonim, 2006, The United State Pharmacopeia, $29^{\text {th }}$ Ed., 3050-3053, United State Pharmacopeia Convention Inc., Rockville
AOAC, 2002, Official Methods of Analysis of AOAC International, AOAC International

Harmita, 2004. Petunjuk Pelaksanaan Validasi Metode dan Cara Perhitungannya. Departemen Farmasi FMIPA-UI :Jakarta.

Karmono \& Cahyono., 1978 Pengantar Penentuan Kualitas Air. Serayu Valley Project, NUFFIC-UGM.

Miller, J.M and Crowther, J.B., 2000, Analitycal Chemistry in a GMP Enviroment, a Practical Guide, 84-99, John Willey and Sons Inc., New York

Mulja, M., dan Hanwar, D., Prinsip- Prinsip Cara Berlaboratorium yang Baik (Good Laboratory Practice), Majalah Farmasi Airlangga, Vol. III, No.2, 2003.

Purwodarminto, 1976. Kamus Umum Bahasa Indonesia. Jakarta : Penerbit Balai Pustaka.

Rohman, A. 2007. Kimia Analisis Farmasi. Cetakan Pertama. Pustaka Pelajar :Yogyakarta

Shargel, L. 1985. Biofarmasetika Dan farmakokinetika Terapan. Penerjemah Fasich. Edisi kedua. Surabaya : Penerbit Universitas Erlangga. 